\title{
Social vulnerability assessment using spatial multi-criteria analysis (SEVI model) and the Social Vulnerability Index (SoVI model) - a case study for Bucharest, Romania
}

\author{
I. Armaș ${ }^{1}$ and A. Gavriș ${ }^{2}$ \\ ${ }^{1}$ Department of Geomorphology - Pedology - Geomatics, University of Bucharest, 1 Nicolae Bălcescu Avenue, \\ Bucharest, Romania \\ ${ }^{2}$ Department of Tourism and Geography, The Bucharest University of Economic Studies, 13-15 Calea Dorobanților, \\ Bucharest, Romania
}

Correspondence to: A. Gavriș (alexandru.gavris@ rei.ase.ro)

Received: 12 September 2012 - Published in Nat. Hazards Earth Syst. Sci. Discuss.: Revised: 27 January 2013 - Accepted: 11 April 2013 - Published: 18 June 2013

\begin{abstract}
In recent decades, the development of vulnerability frameworks has enlarged the research in the natural hazards field. Despite progress in developing the vulnerability studies, there is more to investigate regarding the quantitative approach and clarification of the conceptual explanation of the social component. At the same time, some disasterprone areas register limited attention. Among these, Romania's capital city, Bucharest, is the most earthquake-prone capital in Europe and the tenth in the world. The location is used to assess two multi-criteria methods for aggregating complex indicators: the social vulnerability index (SoVI model) and the spatial multi-criteria social vulnerability index (SEVI model). Using the data of the 2002 census we reduce the indicators through a factor analytical approach to create the indices and examine if they bear any resemblance to the known vulnerability of Bucharest city through an exploratory spatial data analysis (ESDA). This is a critical issue that may provide better understanding of the social vulnerability in the city and appropriate information for authorities and stakeholders to consider in their decision making. The study emphasizes that social vulnerability is an urban process that increased in a post-communist Bucharest, raising the concern that the population at risk lacks the capacity to cope with disasters. The assessment of the indices indicates a significant and similar clustering pattern of the census administrative units, with an overlap between the clustering areas affected by high social vulnerability. Our proposed SEVI model suggests adjustment sensitivity, useful in the expertopinion accuracy.
\end{abstract}

\section{Introduction}

Environmental disasters are the combined result of stress and exposure on one hand, and the fragility and vulnerability of the human society on the other hand (Weichselgartner, 2001; Turner et al., 2003; Adger et al., 2004; UN/ISDR, 2004; Downing and Patwardhan, 2004; Kasperson and Kasperson, 2005; Birkmann, 2006b). As the amount of losses from disasters increases at a striking pace, to understand and to define vulnerability becomes highly important, especially concerning practical applications and methods. The common understanding of vulnerability and the ability to measure it become keys to addressing disasters through managing the consequences and setting targets (Kasperson and Kasperson, 2005; Birkmann, 2006a).

The paper examines two multi-criteria methods that aggregate complex indicators, aiming to reveal the social vulnerability of the city of Bucharest in an earthquake context and to explore the statistical results in a spatial approach. We also aim to introduce a less-known geographical region to many readers and in this way expand the empirical evidence of vulnerability assessment.

The following topics introduce the emergence of the concept, emphasizing the coexistence of different ways to approach social vulnerability from the view of biophysical and social sciences. In the paper we use a model of conceptualization of vulnerability that consists of two approaches; Füssel (2005): a human geography approach aiming to understand the vulnerability of a system to adverse effects of hazards, in this case Bucharest city's area to the earthquake 
hazard, and a human ecology approach that aims to ascertain who is vulnerable and why. In sections three to seven we show the framework of analysis, we identify the region of concern, arguing the type of hazard involved in the vulnerability assessment and finally, we make comments on the valuated attributes and relate them to the year 2002. Furthermore we used four categories of vulnerability factors ${ }^{1}$, classified by Füssel (2009) to show the framework of analysis and identify the region of concern, indicating the type of hazard involved in the vulnerability assessment.

\section{Organizing framework}

To discern the framework of vulnerability, in this section the paper expands on the historical roots of the concept. To date there is no unique understanding of vulnerability (Fuchs et al., 2007) that proves weak agreement in the field (Villagran de Leon, 2006). While there are significant efforts to develop and improve the concept in different contexts (Adger et al., 2005; Eakin and Luers, 2006; Füssel, 2007a), the vulnerability term remains hampered by an inconsistent conceptual register.

The concept of vulnerability implies an array of different meanings argued from the perspective of the scientific background of the researchers, and the trends of conceptual developments. Split between the assessment of the impact from the technical perspective and the socio-economic factors plus the resilience analysed by social science, vulnerability has the consideration of the receptors as the only common point (Fuchs et al., 2011).

Vulnerability is broadly defined as the "potential for loss" (Petak and Atkisson, 1982; Susman et al., 1983; Mitchell, 2000; Thywissen, 2006), or as a predictive variable that designates the potential for being harmed relative to the elements at risk and event intensity (Kates, 1985; Dow, 1992; Ionescu et al., 2009). Other authors introduced the human element as the "property of life" (Cutter et al., 2000), as the main potential risk factor when hazards occur. This approach triggered by the United Nations Disaster Relief Oraganization (UNDRO) emphasizes that "vulnerability is the degree of loss to a given element or set of elements at risk, resulting from the occurrence of a natural phenomenon of a given magnitude" (UNDRO, 1982, p. 5). With good support from a high number of studies, different methodologies analysing vulnerability emerged and other definitions were formulated. The conceptual framework expanded with the inclusion of coping and resilience concepts (Blaikie, 1994; Hewitt, 1997; Blaikie et al., 2004; Cutter and Emrich, 2006; Yarnal, 2007). But in

\footnotetext{
${ }^{1}$ The four categories are: IS (internal socio-economic - household income, social life, access to information), IB (internal biophysical - topography, environmental conditions, land cover), EB (external biophysical - severe hazards, earthquake etc.) and ES (external socio-economic - national, regional, international policies, economic globalization).
}

the social sciences, vulnerability lacks a unified definition (Timmerman, 1981; Liverman, 1990; Cutter, 1996; Weichselgartner, 2001; Kasperson and Kasperson, 2005; Thywissen, 2006; Fuchs et al., 2007) with different interpretations of the same concept (Miller et al., 2010).

The use of the concept of vulnerability in the social framework was introduced by O'Keefe et al. (1976) to explore the key role played by socioeconomic factors in creating a weakness in responding to, and recovering from, the effects of extreme natural events. By the early 1980s, a number of theoretical developments were made (White, 1973; O'Keefe et al., 1976; Westgate and O'Keefe, 1976; Haas et al., 1977; Burton et al., 1978) alongside numerous case studies. The growing literature provided support to evaluate and explore the vulnerability concept for the first time (Timmerman, 1981). Susman et al. (1983) also emphasized the specific social inequalities that define vulnerability. Thus began the understanding of social vulnerability as the capacity of society to cope with hazards and their effects (Blaikie, 1994; Bohle et al., 1994; Cutter, 1996; Cutter et al., 2003).

Some important conceptual models were developed to give disaster managers a framework for understanding vulnerability to disasters and for reducing them: capacities and vulnerabilities analysis (CVA) (see Anderson and Woodrow, 1989), the Risk-Hazard model (Burton and White, 1993), the Pressure and Release (PAR)/access models (Blaikie, 1994; Blaikie et al., 2004), Internal-external model (Bohle, 2001), BBC (Birkmann and Wisner, 2006), Social vulnerability models (see Preston et al., 2011), Expanded-Vulnerability Framework (Turner et al., 2003). Their scrutiny lead to principles to follow (Füssel, 2007a), addressing key challenges of vulnerability (Preston et al., 2011), or adapting the advantages of other models and proposing the modelling of vulnerability (Marchand, 2009).

Although recent work generated guidelines and clarification (Birkmann and Wisner, 2006; Füssel, 2007b; Miller et al., 2010; McEntire, 2011), in a large number of studies, the conceptual development of vulnerability suffers from the lack of clear relation between the theory and the empirical work (Zou and Thomalla, 2008). Being more politically driven - IHDP (International Human Dimensions Programme on Global Environmental Change) (Dyck, 2001), it puts pressure on the allocation of resources and the evaluation of the effects regarding the financial investment for managing vulnerability. In this context, to manage social vulnerability converges towards institutional involvement (Renn and Walker, 2008; Gaillard, 2010), while other directions emphasize the critical importance of disasters social dynamics and of barriers to the science-policy interface (Dowty and Allen, 2011; Kasperson and Berberian, 2011).

To provide accessible solutions to the policy makers, vulnerability research focuses on the conceptual understanding and the solutions for quantification. Current studies follow a trend that provides key assessment of the elements at risk, whether they are individuals, communities, regions, or 
complex systems, alongside explanation of the methodological background.

Our paper builds on the main strands of vulnerability research and combines traditional with up-to-date approaches, performing a multi-criteria analysis in a spatial manner. The vulnerability approach comes from the social sciences perspective, which contests the physical view that considers population as an "undifferentiated mass". From the social sciences perspective on vulnerability, the hazards may be natural while the disasters are not. The pattern of disasters interconnects with the social class system and the position of advantage or disadvantage that a particular group occupies. In this context, some people are more affected by the distribution and growth of risks (Beck, 1992). A variation of ascribed characteristics of people such as: class, gender, age, ethnicity, disability and others determines a position of advantage or disadvantage regarding disasters.

Social vulnerability is context-dependent and, by its nature, the result of a concatenation of factors, as highlighted by Wisner and Luce (1993). Particularities of socio-ecological contexts can generate diverse patterns of vulnerability. In this study, a social vulnerability approach connects to the perspective emphasized by Steinführer et al. (2009), which expresses that everyone may be at risk, but some social groups may have a better response to disasters in specific circumstances. The concept of social vulnerability is used similarly to the one that Blaikie (1994) proposed. From this perspective, the social vulnerability creates a potential instability that results from scarcity of resources (material and non-material), identifiable in an area. Major events can easily destabilize the precarious equilibrium established in areas with high social vulnerability. Disasters result from the double interaction between hazard processes and social conditions, which actively construct the form and scale in which those natural processes expresses themselves (Morrow, 1999; Blaikie, 1994; Tapsell et al., 2005).

\section{Aim and motivation}

Our research belongs to the broad area of quantitative assessment of vulnerability and index construction. The working definition overlaps with the hazards of place model (Cutter et al., 2003), whereby measurement of societal features enables aggregation of results for, and spatial identification of vulnerability.

The structural design of vulnerability indices (Guillaumont and Simonet, 2011) appears as the most outstanding methodology with numerous applications alongside its three variants (Tate, 2012). More advanced assessments rely on integrating GIS-based modelling (Rashed and Weeks, 2003; Ebert et al., 2009). The starting point was the shift in paradigm (Birkmann, 2006b) that emphasizes the focus on identification, assessment and ranking of vulnerabilities. The main objective is to compare two different models to design social vulnerability: Cutter et al.'s (2003) SoVI (Cutter et al., 2003; Cutter and Finch, 2008) and the SEVI semi-quantitative technique based on a GIS-supported raster database and built as a spatial decision problem of vulnerability. Building and validating complex social vulnerability indices for Bucharest was a secondary aim. The two methodological constructions at the core of the inquiry rely on what is currently the most widely used model of vulnerability (Cutter et al., 2003; Adger et al., 2004; Vincent, 2004; Wisner, 2006; Mustafa et al., 2011; Tapsell et al., 2010). The two indices resulted from a composite approach of factor analysis, while a different aggregation was used: linear (SoVI model) vs. weighting (SEVI model) (Fig. 1).

The SoVI model (Cutter et al., 2003) evolved from the hazards of place model (Cutter, 1996) and of a previous variant (Cutter et al., 2000). It aims to examine the components of social vulnerability and determine whether they can be used to predict disaster impacts. As the model gained support from other researchers, it allowed for improvements, such as depicting temporal changes of vulnerability (Cutter and Finch, 2008; Schmidtlein et al., 2008). Moreover, many studies scrutinized the model in the US and nearby areas, at various scales (Boruff et al., 2005; Cutter and Emrich, 2006; Borden et al., 2007; Boruff and Cutter, 2007; Cutter and Finch, 2008; Schmidtlein, 2008; Schmidtlein et al., 2008; Yeletaysi et al., 2009; Morath, 2010), and more recently in Europe (de Oliveira Mendes, 2009; Holand et al., 2011; Holand and Lujala, 2013), to show different constructs in algorithm (Chakraborty et al., 2005; Rygel et al., 2006; Yeletaysi et al., 2009; Lopes et al., 2010) and changes in the way in which variables should be interpreted to the local conditions. In one respect, the model was de-constructed to a more complex index - Disaster Preparedness Index (Simpson and Katirai, 2006). The outcome and the critical review of the index (Rygel et al., 2006; Schmidtlein, 2008), as well as the algorithm enhancement (Schmidtlein et al., 2008) highlighted the robustness of the index and the theoretical significance of variables.

The theoretical background for the multi-criteria evaluation (SEVI) stands on the analytical hierarchical process (AHP), developed by Saaty $(1980,2008)$, as a combination of expert judgement and statistical methods used to determine relative weights (Gall, 2007). The main difference between the SEVI method and conventional multi-criteria decision making techniques is its facility to capture the evaluation criteria variation across space. The inductive design structure of SEVI allows for the gathering of spatial evidence, which supports or rejects an alternative, using divergent perspectives on social vulnerability.

A characteristic of the study is the detailed scale of analysis for a large city. The paper builds on previous research (Armaș, 2006; Armaș and Avram, 2008; Armaș, 2008b; Armaș et al., 2008) and integrates the results. The scale of analysis proves essential for the dimensions of vulnerability 


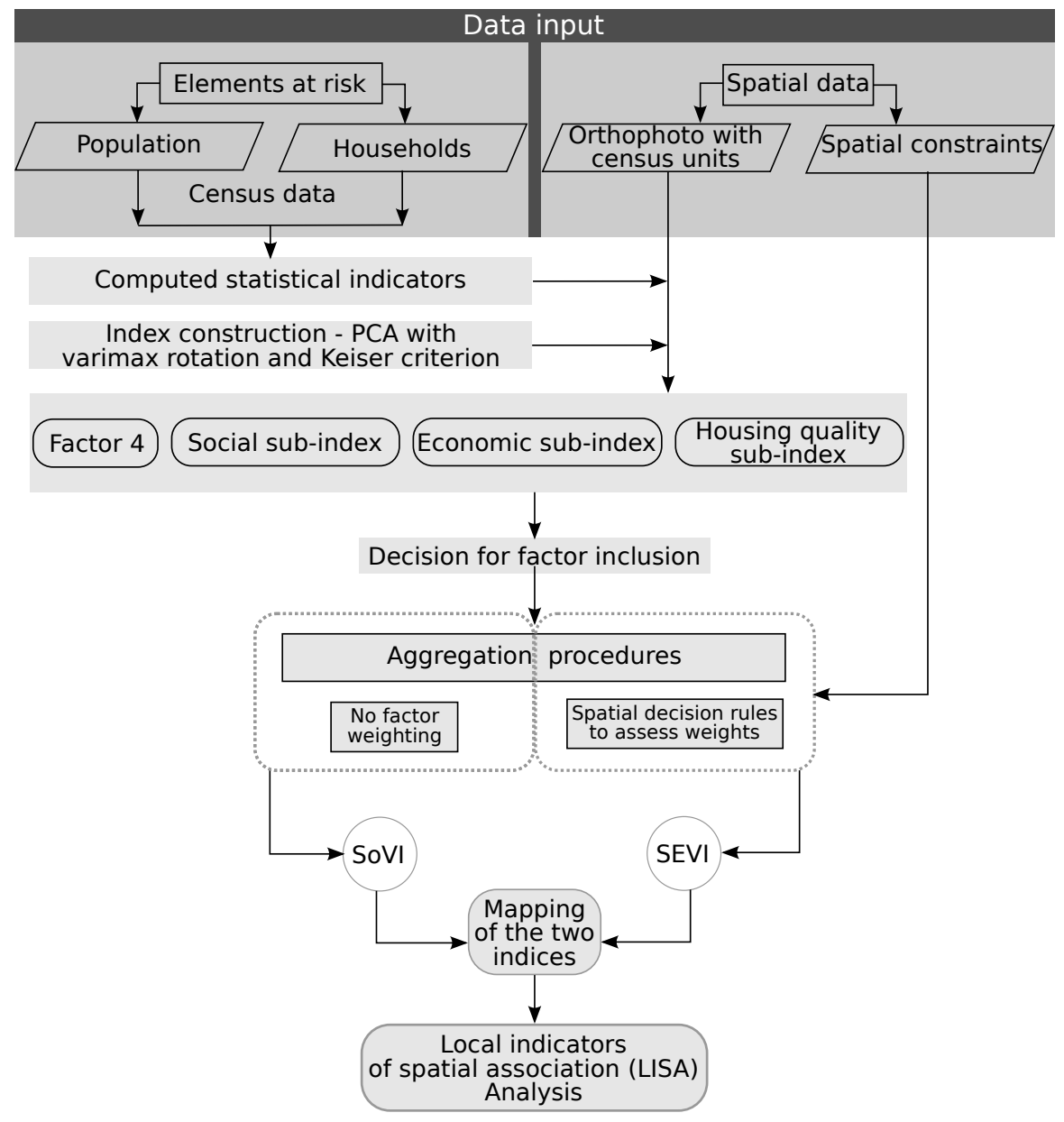

Fig. 1. General framework for building the social vulnerability indices.

(Fekete, 2009) and the social attribute in particular (Gall, 2007). The general issues concerning the scales of analysis for vulnerability (Cutter et al., 1996; Turner et al., 2003; Fekete et al., 2010) and related indicators were discussed in detail in studies regarding river floods in Germany (Fekete, 2009; Fekete et al., 2010; Fekete, 2010) and alpine hazards (Papathoma-Köhle et al., 2011). For urban space in which the census tracts is the aggregation area, other studies revealed the relevance of the unit selection (Schmidtlein et al., 2008).

The set area for assessment is Bucharest due to its high vulnerability to earthquakes and the profound socioeconomical changes that the city has undergone over the past two decades. Furthermore, our research tries to fill a gap, given the absence of recent studies on social elements at risk - specific for this location - as well as the need for improvement of social vulnerability analysis of Bucharest. Finally, we analyse the clustering results of the two social vulnerability indices. The results offer a good image of possible vulnerability hot spots that are likely to remain the same over time.

\section{Study area}

Generally speaking, an element at risk is vulnerable, as it is exposed and more susceptible to impact, according to the "first law of geography" that states "near things are more related ..." (Tobler, 1970, p. 236). The tendency to test diverse methods and concepts of social vulnerability is mainly directed towards urban environments, which contain the highest number of people at risk and the greatest potential for material losses. In this study, specific natural stressors were measured against social vulnerability since strong earthquake occurrence is high (4 large over $M_{\mathrm{w}}=7$ in the past century and 6 medium, over $M_{\mathrm{w}}=5$ in the last decade), as other types of risks have a lesser impact in Bucharest.

Bucharest is located in the Vlăsia Plain, in the lower part of the Argeș River basin with an alluvial soil that covers deep sedimentary deposits. These morphological and hydrological elements are important, as the distance of Bucharest from the most active seismic source of Romania - Vrancea - is just about $150 \mathrm{~km}$ from the main seismic zone (Fig. 2), the soft deposits of soil enhancing the tremors (Lang et al., 2011). 


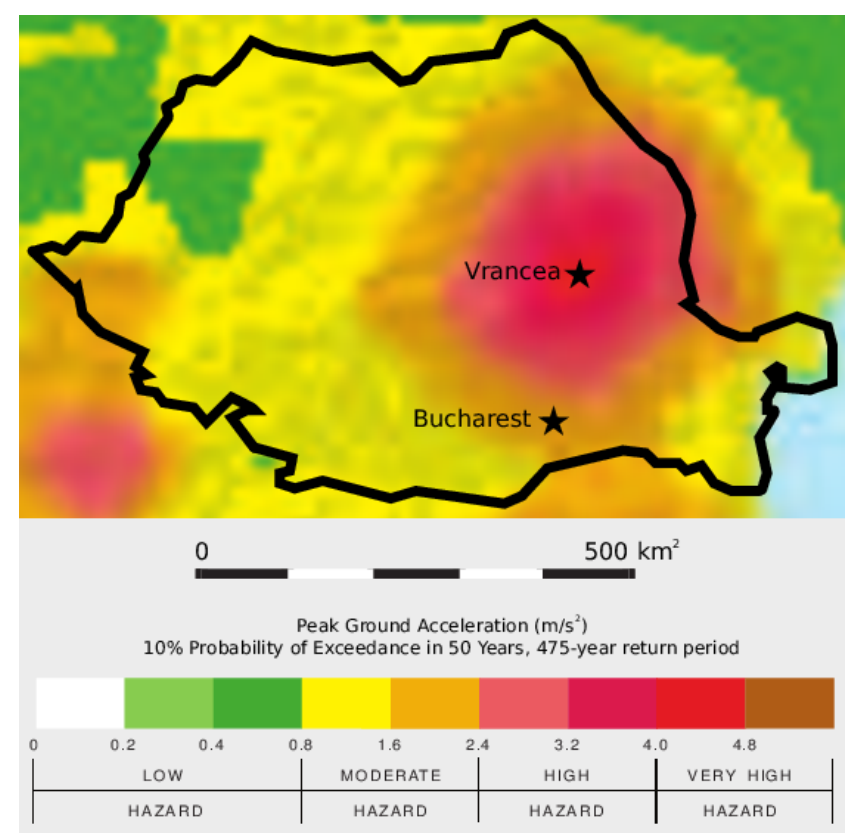

Fig. 2. Romania seismic hazard map, source: modified after Giardini et al. (1999).

The key features of Vrancea earthquakes, in terms of urban risk studies, is the prevalence of a long period of radiation (1-2 s) for strong shocks and the depth of the epicenter (90$150 \mathrm{~km}$ ) that produces large earthquakes with damaging effects on buildings 8-12 floors high (Mândrescu and Radulian, 1999; Radulian et al., 2006; Mândrescu et al., 2007; Zaharia et al., 2008). The high-magnitude seismic events of $1940\left(M_{\mathrm{w}}=7.7\right)$ and of $1977\left(M_{\mathrm{w}}=7.5\right)$ caused tremendous damage to many buildings (Mărmureanu et al., 2011). In the case of the 1977 event, the rough estimation of damage equaled $\$ 1.45$ billions (WB, 1978), $70 \%$ of which in Bucharest. The fatalities exceeded 1400 people, over 7500 were injured and some 35000 families remained homeless (BSSA, 1978).

The city records almost 2 million inhabitants (2012 Romanian National Institute of Statistics data) and a heterogeneous surface from a functional and architectural point of view (Fig. 3). The structure of the city follows a concentric pattern: old buildings dominate the central part surrounded by a mix of pavilion residential buildings and blocks of flats. Large urban estates with blocks of flats of 5 and 10 floors, built mainly in the communist period, represent the largest part of the city. In between the blocks of flats rural areas remain visible, despite their inclusion into the city during the communist regime. The 1977 earthquake was an important moment after which the city planners started to remodel the city. After the earthquake, there began a process of demolishing old buildings and planning new areas. The central area of the city was heavily transformed, followed by areas where seismic security measures represented a priority, especially along the main thoroughfares. Despite the massive intervention, many buildings with structural problems remained due to their historical importance or their location, at the back of new blocks of flats ${ }^{2}$.

\subsection{The communist Bucharest}

After the Second World War, the communist projects focussed on developing industry attracted large numbers of people, mainly from the rural parts of the country. They received a good status as working class, meaning a free dwelling and a work place in the industry sector. The new way of living was more than expected, so people largely supported the regime, without much care for other life aspects. The required residences for the newly arrived inhabitants forced a fast development of buildings, mainly blocks of flats, with little concern about the earthquake risk. This situation amplified in the 1960s, when the city adopted the soviet model of urban planning and concentrated on efficiency and profitability. The Romanian model of architectural planning, imposed next, favoured geometry and aestheticism over social aspects. In the 1970s, the city planning policies involved new measures aimed to increase the urban density as a way of better space management. Blocks of flats over 5 levels were the main focus of planners and the apartments built became smaller. The inhabited surface of dwellings, in general low (under $30 \mathrm{~m}^{2}$ ), faced some complication with the increase of family members as a consequence of the powerful pronatalist policies. Initially these characteristics changed after the 1977 disaster, but because of the large investment required for foreign technologies and materials, the quality of the new buildings improved slightly. The authorities considered Romanian technologies good and thought they should be used instead. The finalization of the large projects and the start of the new ones (redevelopment of the city centre) removed any further major investment from the social utilities or building rehabilitation. At the end of 1980s, Bucharest recorded a housing crisis, with people having to wait to receive an apartment and with people forbidden to move into the city if they did not possess a city ID card. This proves important for the next period, when many people who worked in Bucharest, but lived outside the city "invaded" some of the unfinished buildings, starting to develop real ghetto areas.

\subsection{The post-communist Bucharest}

The communist planners wanted to uniform the entire city. After the 1989 revolution the city's development froze, and only slight alterations were made to the city plan. In the new period, the population vulnerability is considered to originate from the indifference of the population to earthquake risks, local tensions, poor living conditions in terms of the

\footnotetext{
${ }^{2}$ Planners and builders had tried to cover the rural image and the fact that they could not finish the projects in the time imposed by the communist authorities.
} 
external appearance of buildings and building management, poor management of the communal or public areas by the city's administration, development of segregation once the barriers of communist doctrine became loose, and an increase in number of people that required social assistance (Armaș, 2006, 2008b; Mionel, 2011). The vulnerability resulted as a combination of rapid changes and a slow adaptation of the population to the socio-economic transformations, population used to respond to a centralized system of coordination and leadership.

The communists' housing estates continued to be highly homogeneous from a demographic point of view. This was especially true for the neighbourhoods with big blocks of flats. But in the central part of the city and in the rural-like neighbourhoods, the influence was not powerful enough to change the demographic distribution of the population. In these old areas, demographic ageing developed because people were coming to the end of their working service or were already pensioned. The purchasing power of elderly people was low and the indifference to the new transformations (from communism to capitalism) determined an increase of social vulnerability.

Regarding the economic issues of the first $13 \mathrm{yr}$ since the revolution, Bucharest recorded a transitional phase, marked by a form of liberalisation with populist accents, that led to closure and restructuring of numerous industrial areas and factories. At the time of the 2002 census, there were 35 industrial estates, employing 360000 inhabitants, which represented over $40 \%$ of the total active working population of the city. Once representative for the economy of the city and the country, Bucharest's industry remained highly subsidized and sustained politically, increasing the social vulnerability. At that time, workers received 20-30 times the equivalent of their wages as redundancy compensations if they left the factory. The majority of people invested their money mainly for internal repairs to the dwellings that they bought from the state after the collapse of communism. According to Romanian housing legislation, all the tenants have a share of the freehold and therefore are all responsible for major repairs and together own the land on which the block was built. No major repairs continued after 1989, because the tenants could not afford major repairs. Besides, the surrounding areas around the blocks of flats became neglected, a clear sign that they were not managed properly by the new owners of these blocks.

The high number of housing estates in the former industrial zones represents another facet of vulnerability at the economic level. A strong earthquake may affect such zones where population density is high and where it has already invested massively ${ }^{3}$. Only recently, a law (260/2008) to protect dwellings against the hazards was issued. The risk is even

\footnotetext{
${ }^{3}$ Romanians consider it essential to own a house or apartment as opposed to renting it. That is why, after 1990, people directed most of their financial assets to the real estate sector.
}

higher in an unregulated capitalist city, where "liberal legislation" favoured the construction of housing estates, with disregard to the strict building regulations in a city prone to intense earthquakes.

After the end of the communist period, the city's housing market experienced a fast-paced liberalization. The state allowed the residents and tenants to buy apartments and houses they previously rented from the state. It determined a high private ownership (over $90 \%$ of housing stock). Moreover, some of the housing estates under construction or which were in an advanced state of degradation were illegally occupied, being later bought or leading to ownership litigation. These housing units were occupied by large families on low incomes and of rural origin trying to take advantage of the opportunities of the city. The situation worsened as in these buildings or normal blocks of flats built before the earthquake the planned consolidation stopped. It is normal to see cracks in the buildings all over the city, but especially if one enters such buildings. After 2000, some parts of the population began to restructure the interior of their own dwellings to make larger rooms, but without any official approval or construction knowledge.

\section{Methodology}

Selecting the evaluation of the two indices of social vulnerability involves analysis of different methodologies and their connection to a common point. This may be a denominator of vulnerability (Stânga and Grozavu, 2012) or a different methodology that provides insight over the results. The methodological steps involve data presentation, indicator construction and index design. Finally, the analytical part reveals the direction followed to assess the two multi-criteria methods.

\subsection{Data}

The study relies on the 2002 census data at tract level. The census tracts are the smallest units in Bucharest for which the INS (National Institute for Statistics) offers (scarce) information on social and economic variables. Data included are inventories of population characteristics, base economic data, and data on housing conditions. The Urban and Metropolitan Planning Centre of Bucharest (CPUMB) offered information about the spatial limits of the residential areas. We investigated 154 census units covering the entire administrative area of Bucharest, representing $228 \mathrm{~km}^{2}$; the built up areas represented slightly over $70 \%$.

Because studies on individuals and households confirmed good results on the quantification of social vulnerability (Levine, 2004), a small set of household interviews was used to confirm the accuracy of indicator selection at census level. Information about hazard perception and mitigation abilities were obtained at household level for different 




Fig. 3. Urban structure of Bucharest, source: modified after Suditu (2007, p. 131).

parts of Bucharest through studies executed during 19972009 (Armas, 2006, 2008a,b; Armas and Avram, 2008). The drawback of such micro-scale research is the large amount of redundant data. To maintain the correlation with previous data and with the main aspect of analysis - social vulnerability - we considered not using the buildings' physical characteristics.

Since we intend to continue assessing social vulnerability in Bucharest, and compare it with regional results, we have endorsed a set of accessible data, made up of indicators and variables, as provided, that are easy to compute, while keeping track of the reference results in the literature.

\subsection{Indicators}

While many methodologies of assessing vulnerability exist at different scales and systems, the paper follows an indicatorbased approach. The literature of vulnerability contains an array of indicators and characteristics, but how these are understood is conditioned by the complexity of the problems involved in measuring vulnerability. In this context, an indicator can measure the variable of interest either directly, or it will measure another variable that serves as a substitute of the variable of interest (Babbie, 2007). To achieve the goal of this research, the indicators developed here relate strictly to the social component (measured by a series of socio-economic features) (Cutter et al., 2000).

Social vulnerability indicators consider a core set of vulnerability dimensions, as past research provides: age, gender, income, unemployment, dependence on social services, residential property (renters, housing conditions), infrastructure (medical services, emergency management institutions), occupation, social networks, education, urban-rural dichotomy, population growth, built environment, health status, etc. (Twigg, 2001; Downing and Patwardhan, 2004; Blaikie et al., 2005). The availability of indicators determined and/or restricted the dimensionality of indices. The selection of indicators for an index is still a product of subjective choice, relying on the aim of the study, the theoretical frameworks, availability and accuracy of social vulnerability data and statistical results (Diener and Suh, 1997; Niemeijer, 2002).

In this study, reviewing the literature and expert opinion helped to identify vulnerability dimensions. The international expertise in the field (Blaikie, 1994; Davidson and Freudenburg, 1996; Fordham, 2000; Pelling, 2003; Cutter et al., 2003; Dayton-Johnson, 2004; Dwyer et al., 2004; Eakin and Luers, 2006) was connected to the previous 
Table 1. Statistical variables.

\begin{tabular}{|c|c|c|}
\hline No. & Variables & Symbol \\
\hline 1 & Total no. of persons on census unit (census population) & $N_{\mathrm{p}}^{\mathrm{t}}$ \\
\hline 2 & Total no. of households on census unit & $N_{\mathrm{h}}^{\mathrm{t}}$ \\
\hline 3 & Total no. of children on census unit & $N_{\mathrm{c}}^{\mathrm{t}}$ \\
\hline 4 & Total no. of women on census unit & $N_{\mathrm{w}}^{\mathrm{t}}$ \\
\hline 5 & Total no. of women having 3 or more children on census unit & $N_{\mathrm{w} 3}^{\mathrm{t}}$ \\
\hline 6 & Total no. of women of over $15 \mathrm{yr}$ giving birth to a live child & $N_{\mathrm{w} 15}$ \\
\hline 7 & Total no. of persons with minimum education level on census unit & $N_{\mathrm{me}}^{\mathrm{t}}$ \\
\hline 8 & Total population over $10 \mathrm{yr}$ of age & $N_{\mathrm{p} 10}^{\mathrm{t}}$ \\
\hline 9 & Total area of occupied space in the residences & $N_{\text {ho }}^{\mathrm{t}}$ \\
\hline 10 & Total no. of wage earners per household on census unit & $N_{\mathrm{we}}^{\mathrm{t}}$ \\
\hline 11 & Total no. of unemployed persons on census unit & $N_{\mathrm{u}}^{\mathrm{t}}$ \\
\hline 12 & Total no. of low income wage earners on census unit & $N_{1}^{\mathrm{t}}$ \\
\hline 13 & Total no. of men on census unit & $N_{\mathrm{m}}^{\mathrm{t}}$ \\
\hline 14 & Total no. of high income wage earner men on census unit & $N_{\mathrm{hm}}^{\mathrm{t}}$ \\
\hline 15 & Total no. of high income wage earner women on census unit & $N_{\mathrm{hw}}^{\mathrm{t}}$ \\
\hline 16 & Total area of dwelling rooms (bedrooms, living rooms) on census unit & $N_{\mathrm{a}}^{\mathrm{t}}$ \\
\hline 17 & Total no. of rooms on census unit & $N_{\mathrm{r}}^{\mathrm{t}}$ \\
\hline 18 & Total no. of private/owned households on census unit & $N_{\mathrm{o}}^{\mathrm{t}}$ \\
\hline 19 & Total no. of private/owned households with 5 or more rooms on census unit & $N_{\mathrm{o} 5}^{\mathrm{t}}$ \\
\hline 20 & Total no. of economically active population & $N_{\mathrm{cvt}}^{\mathrm{t}}$ \\
\hline 21 & Total no. of social dependent people & $N_{\mathrm{d}}^{\mathrm{t}}$ \\
\hline 22 & Total population over $65 \mathrm{yr}$ of age & $N_{\mathrm{e}}^{\mathrm{t}}$ \\
\hline
\end{tabular}

analysis of the local conditions concerning vulnerability against earthquake and the perception of population (Armas, 2006, 2008a,b). Twenty-two statistical variables were selected (Table 1) to compute complex indicators and indices.

The importance of scale was assessed in relation to previous studies on Bucharest. Considering its location in the Dâmboviţa River's meadow and the age of the buildings, the central part of the city was especially analysed, being the most exposed area to seismic risk and recording a high social vulnerability profile (Armas, 2008b). Previously mentioned studies on Bucharest showed that vulnerability indicators were correspondent at the household and neighbourhood level. In this study we analysed the vulnerability dimensions at the former two levels, but also at census level to check the scale variation and to offer a representative outlook. The obtained results yielded good support to introduce the same indicators into the present research.

Other indicators that proved relevant in other studies were unavailable for Bucharest. Limitations in getting the data are not the main reason for the current index construction, but rather the evolution of the Romanian society as recorded in Bucharest. During the communist period, the process of homogenization targeted the urban population. At lower intensity, the homogenization process continued throughout 1990-2000 period. We consider that there are elements that emerged during the post-communist period and that they are likely to influence socio-economic vulnerability, but weak and scarce at that time: immigrants, new socio-economic classes, increase of minority populations. The changes did become somewhat more visible after 2000, but they did not reflect in the 2002 census data. Furthermore, the variance (of over $88 \%$ ), which is explained by the principal component analysis - PCA (Jolliffe, 2005), reports that the determined composite indicators are representative for the entire dataset.

Social vulnerability has been observed in the light of three sub-indices of social vulnerability dimensions: "social", "economic" and "housing quality" (Tapsell et al., 2002, 2010). The sub-indices rely on social and economic indicators, ranging from demographic indicators to the constructed environment, expressed as ratio of housing characteristics per census unit. These indicators underline specific social groups that might be more vulnerable to seismic risks. The data from Table 2 and Fig. 1 display the indicators used in the study. The variables were signed and grouped according to 
Table 2. Indicators used to assess social vulnerability in Bucharest.

\begin{tabular}{|c|c|c|c|c|}
\hline Sub-indices & Computed statistical indicators (2002) & Symbol & Eq. & Sign. \\
\hline \multirow[t]{9}{*}{ Social Vulnerability } & Ratio of elderly population (over $65 \mathrm{yr}$ ) & $N_{\mathrm{e}}$ & $N_{\mathrm{e}}^{\mathrm{t}} / N_{\mathrm{p}}^{\mathrm{t}}$ & $(+)$ \\
\hline & Ratio of female population in total population & $N_{\mathrm{f}}$ & $N_{\mathrm{f}}^{\mathrm{t}} / N_{\mathrm{p}}^{\mathrm{t}}$ & $(+)$ \\
\hline & Ratio of children (under $5 \mathrm{yr}$ ) & $N_{\mathrm{c}}$ & $N_{\mathrm{c}}^{\mathrm{t}} / N_{\mathrm{p}}^{\mathrm{t}}$ & $(+)$ \\
\hline & Ratio of widows in female population & $N_{\text {wi }}$ & $N_{\mathrm{wi}}^{\mathrm{t}} / N_{\mathrm{w}}^{\mathrm{t}}$ & $(+)$ \\
\hline & Housing density & $N_{\mathrm{h}}$ & $N_{\mathrm{p}}^{\mathrm{t}} / N_{\text {ho }}^{\mathrm{t}}$ & $(+)$ \\
\hline & Average number of wage earners per household & $N_{\text {we }}$ & $N_{\mathrm{we}}^{\mathrm{t}} / N_{\mathrm{p}}^{\mathrm{t}}$ & $(-)$ \\
\hline & Minimum level of education & $N_{\text {me }}$ & $N_{\mathrm{me}}^{\mathrm{t}} / N_{\mathrm{p} 10}^{\mathrm{t}}$ & $(+)$ \\
\hline & Women with 3 children or more & $N_{\mathrm{w} 3}$ & $N_{\mathrm{w} 3}^{\mathrm{t}} / N_{\mathrm{w} 15}$ & $(+)$ \\
\hline & Ratio of dependent people in total population & $N_{\mathrm{d}}$ & $N_{\mathrm{d}}^{\mathrm{t}} / N_{\mathrm{p}}^{\mathrm{t}}$ & $(+)$ \\
\hline \multirow[t]{4}{*}{ Economic Vulnerability } & Ratio of unemployed & $N_{\mathrm{u}}$ & $N_{\mathrm{u}}^{\mathrm{t}} / N_{\mathrm{cvt}}^{\mathrm{t}}$ & $(+)$ \\
\hline & Ratio of low incomes & $N_{1}$ & $N_{1}^{\mathrm{t}} / N_{\mathrm{p}}^{\mathrm{t}}$ & $(+)$ \\
\hline & Ratio of high incomes (women) & $N_{h w}$ & $N_{h w}^{\mathrm{t}} / N_{\mathrm{w}}^{\mathrm{t}}$ & $(-)$ \\
\hline & Ratio of high incomes (men) & $N_{\mathrm{hm}}$ & $N_{\mathrm{hm}}^{\mathrm{t}} / N_{m}^{\mathrm{t}}$ & $(-)$ \\
\hline \multirow[t]{5}{*}{ Housing Quality (Security) } & Room occupancy per household & $N_{\mathrm{o}}$ & $N_{\mathrm{p}}^{\mathrm{t}} / N_{r}^{\mathrm{t}}$ & $(-)$ \\
\hline & Average dwelling room area on census unit & $N_{\text {ra }}$ & $N_{\mathrm{a}}^{\mathrm{t}} / N_{r}^{\mathrm{t}}$ & $(-)$ \\
\hline & Dwelling population density on census unit & $N_{\mathrm{dp}}$ & $N_{\mathrm{p}}^{\mathrm{t}} / N_{\mathrm{h}}^{\mathrm{t}}$ & $(+)$ \\
\hline & Average no. of private/owned dwellings with 5 or more rooms on census unit & $N_{\mathrm{o} 5}$ & $N_{\mathrm{o} 5}^{\mathrm{t}} / N_{\mathrm{o}}^{\mathrm{t}}$ & $(-)$ \\
\hline & Average room area per person on census unit & $N_{\mathrm{pa}}$ & $N_{a}^{\mathrm{t}} / N_{\mathrm{p}}^{\mathrm{t}}$ & $(-)$ \\
\hline
\end{tabular}

The sign indicates whether the variable may be an indicator of increased or decreased social vulnerability $(+=$ increases vulnerability, $-=$ decreases vulnerability).

the vulnerability research (Twigg, 2001; Cutter et al., 2003; Blaikie et al., 2005), as well as on the perception of personal vulnerability in earthquakes, studies performed in Bucharest between 1997 and 2009, on samples of 500 to 1300 respondents (Armaș, 2006, 2008a,b).

\subsection{Index design: SoVI versus SEVI Model}

Certain benefits sustain the agreement on the use of indices: they are created for a better understanding of the society and its relations, by condensing this complex system into simple terms through numerical data (Diener and Suh, 1997). According to some definitions, indices are "measure(s) of an abstract theoretical construct in which two or more indicators of the construct are combined to form a single summary score" (Carmines and Wood, 2004, p. 485). The absence of a well-established framework, where the concepts and methodology may be used at different levels of analysis, argues that subjective judgement still plays a major role in index design (Diener and Suh, 1997).

First, in order to aggregate the indicators at indices level, they have to undergo a series of standardization techniques. Among widely accepted standardization techniques we note the use of min-max standardization, linear scale transformation, value/utility functions, probabilities, distance to reference, fuzzy approach, and $z$ score transformations (Malczewski, 1999; Zeng and Zhou, 2001; Gall, 2007). Indices may also differ in point of the number of aggregation levels.

A further requirement is to include weights, because different indicators and sub-indices usually have different levels of importance. Indices also differ in the weighting of indicators (Voogd, 1983). In some cases, even using the same concept and methodology, differences may appear (Holand et al., 2011) and a need for adapting the indices has to be considered (Holand and Lujala, 2013). For example, an analysis of 7 different indices linked to social vulnerability, (Gall, 2007) found no coherent construction at any level but rather gaps in empirical validity and methodological robustness. Nevertheless, once shortcomings are known, the strategy should involve a common framework, where scientific results are combined with communities' involvement to apply and rectify the analytical framework (Gall, 2007).

Against this background, recent research (Gall, 2007; Füssel, 2007b; Schmidtlein et al., 2008) has sustained the efforts to clarify the concepts of measurement standardization and weighting methodologies, aiming the vulnerability quantification at different scales and in different conditions (Turner et al., 2003; Blaikie et al., 2004; Adger et al., 2005; Birkmann and Wisner, 2006). A detailed review of the index literature 

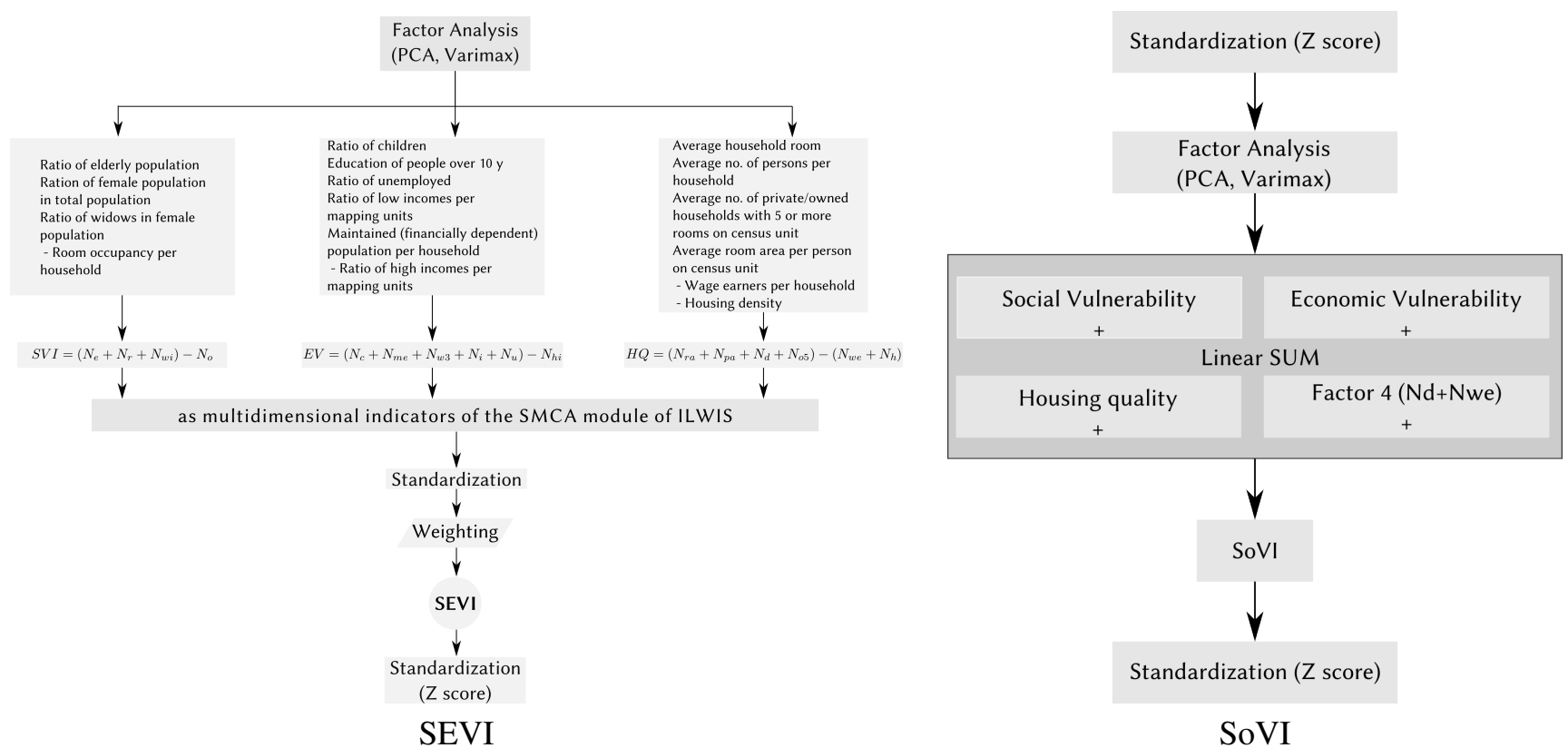

Fig. 4. Index design.

and a general taxonomy widely used to select, classify and assess indicators and indices can be read in Booysen (2002), Birkmann (2006a), Jean-Baptiste et al. (2011).

In our research we examined two multi-criteria methods of aggregating complex indicators: the social vulnerability index (SoVI model) and the spatial multi-criteria social vulnerability index (SEVI model). The working SoVI algorithm used in the study adheres to the initial version introduced by (Cutter et al., 2003), leaving aside subsequent amendments brought by PCA. That is why we attempted to keep the tendency confirmed by other studies that used the index, while the construction changes of the algorithm were sensitive and insufficiently put to the test (Schmidtlein et al., 2008).

The study used the following methodological steps of the SEVI multi-criteria technique (Fig. 4), based on a GISsupported raster dataset: breaking down the complex problem into sub-indices; selection of the significant indicators; standardization of indicators to a range of $0-1$; comparing indicators and sub-indices pair-wise using a hierarchical structure termed "criteria tree" and expressing preference for each pair, calculating a composite index map (Vargas, 1990; Howard, 1991; Keeney, 1992; Yusuff et al., 2001; Keefer et al., 2004; Chen et al., 2008). The use of weights facilitated the combination of indicators and indices into composite index maps, where the performance indices use the formula

$p_{i}=\prod_{l=1}^{h} w_{i}^{l}$ in which $i$ is the indices or sub-indices (standardized value), and $h$ represents the number of levels of the hierarchical structure and refers to the weight of indices $i$ for level $l$.

In the spatial implementation of this technique (Nijmeijer et al., 2001), every indicator and index represents a raster layer, and every pixel/set of pixels of the final composite index map constitutes a different spatial result or alternative of the analysis (for a detailed review of the method see van Westen and Woldai, 2012).

The advantages of using the SMCE module of ILWIS are the maps generated for various working stages, useful in later processing. This characteristic relates to an indirect requirement of the analytic hierarchy process, i.e. use of a smaller number of indicators to avoid inconsistencies in the weighting scheme (Voogd, 1983; Cardona, 2005).

\subsection{Analytical steps}

The structure of the algorithms follows, in the pre-processing stage, the same steps, namely the inductive, statistical approach (relying on statistical relationships to infer leading factors).

Through factorial reduction procedure (PCA, Varimax), the structuring method of the index variables (Tables 1 and 2) revealed three dimensions regarding social vulnerability: a complex social factor (that highlights the degree of solitude of the elderly population, especially widows), the economic factor (in relation to large families), and quality of housing. While the elderly population, mainly widows, concentrated in the central areas of the capital, the low-income 
Table 3. Table after rotation.

\begin{tabular}{|c|c|c|c|c|}
\hline & \multicolumn{4}{|c|}{ Component } \\
\hline & 1 & 2 & 3 & 4 \\
\hline Ratio of dependent people in total population, $N_{\mathrm{d}}$ & 0.935 & & & \\
\hline Minimum level of education, $N_{\mathrm{m} . \mathrm{e}}$ & 0.924 & & & \\
\hline Ratio of children (under $5 \mathrm{yr}$ ), $N_{\mathrm{c}}$ & 0.88 & & & \\
\hline Female single-family households, with three children or more, $N_{\mathrm{w} 3}$ & 0.88 & & & \\
\hline Ratio of high incomes women, $N_{\text {h.w }}$ & -0.765 & & 0.419 & 0.41 \\
\hline Ratio of unemployed, $N_{\mathrm{u}}$ & 0.665 & & & \\
\hline Ratio of low income, $N_{1}$ & 0.625 & & -0.616 & \\
\hline Ratio of widows in female population, $N_{\text {wi }}$ & & 0.931 & & \\
\hline Ratio of elderly population (over $65 \mathrm{yr}$ ), $N_{\mathrm{e}}$ & & 0.885 & & \\
\hline Ratio of female population in total population, $N_{\mathrm{f}}$ & & 0.81 & & \\
\hline Room occupancy per household, $N_{\mathrm{O}}$ & & -0.679 & -0.609 & \\
\hline Average household room area on census unit, $N_{\text {r.a }}$ & & & 0.903 & \\
\hline Average room area per person on census unit, $N_{\text {p.a }}$ & & 0.459 & 0.821 & \\
\hline Housing density, $N_{\mathrm{h}}$ & & -0.566 & -0.742 & \\
\hline Average no. of private/owned households with 5 or more rooms on census unit, $N_{\mathrm{o} 5}$ & 0.536 & & 0.556 & 0.44 \\
\hline Average number of wage earners per household, $N_{\mathrm{w} . \mathrm{e}}$ & & & & -0.904 \\
\hline Household population density on census unit, $N_{\mathrm{d}}$ & & -0.442 & & 0.79 \\
\hline
\end{tabular}

Rotated component matrix. Extraction Method: Principal Component Analysis. Rotation Method: Varimax with Kaiser Normalization. $\alpha$. Rotation converged in 6 iterations, $\beta$. threshold for exclusion $=$ low correlations $(<0.3)$.

population, with many children, lived in the outskirts, in the working class districts.

These factors are significant by the degree of saturation in variables corresponding to the goal of the study, based on the Eigen $>1$ criteria. They account for over $88 \%$ of the social vulnerability variation and will be further comprised in the design of complex SEVI and SoVI indices (Fig. 4).

The factorial reduction procedure indicated statistical significance and showed that data were suitable for factorial analysis: a Kaiser-Meyer-Olkin measure of sampling adequacy is medium high $(>0.7)$, and the highly significant Bartlett's test of sphericity $(4510.312$; Sig. $=0.0001)$ suggests the strength of the correlation of the variables (Table 3). The next step was to gain a maximum variation of factors, functions of combined variables, by applying the Varimax rotation.

SoVI standardization used $Z$ score. The methodological difference was factor aggregation, made by linear summing for SoVI and by weighting for SEVI. We standardized the final results ( $Z$ scores), so that we could represent the indices in terms of standard deviation (Fig. 5).

In the spatial multi-criteria analysis of the SEVI index after factorial reduction, the next step was to aggregate the scores of the indicators in which the selected factors were saturated, and introduced these as multidimensional indicators in the SMCE module of ILWIS software (Fig. 4). Aggregation was determined by the sign of correlation among the variables that saturated the three factors. The multidimensional indicators were standardized under the goal standardization procedure.
Built on the pair-wise comparison method, we weighted sub-indices in a complex social-economic vulnerability index (SEVI) to obtain the final index score (Fig. 4 SEVI). The pair-wise comparison approach is a noncompensatory strategic approach of attributing importance (ordinal) weights, as linear aggregation allows indicators to be compensated (Munda and Nardo, 2003; Nardo et al., 2005). This method showed to be most appropriate for use with MCE techniques (Carver, 1999).

Based on the qualitative expert-based method, which involves assigning weights according to expert's opinion, we deemed that social and economic vulnerability had an equal contribution to raising the general level of vulnerability in the SEVI model, while we interpreted housing quality as an element of reduction of vulnerability. This option gained support from the results of social surveys in Bucharest and other media information from Romania, which emphasized the importance of housing quality in attenuation/amplification of social vulnerability perception (Armaș, 2006, 2008b; Armaș and Avram, 2008).

The construction of this index used the statistical data available for that time, and this imposed some constraints over the results. The factorial reduction procedure and the experience of interviews for various types of natural disasters emphasizes that the spatiality and the type of home ownership are important elements of interior comfort and security, even in situations when the building lacks seismic safety (Beck, 1992; Sunstein, 2002).

We are fully aware of the limitations of housing quality, since this indicator overlooks the fact that housing units 


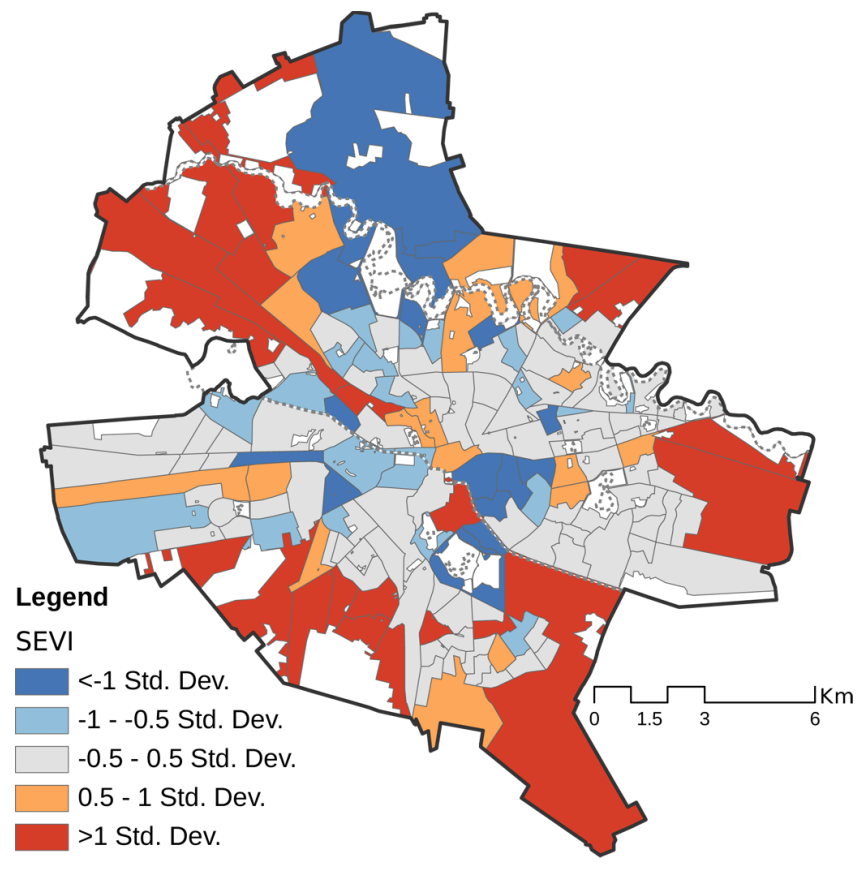

Fig. 5. Indices with added spatial constraints (white color are parks, barren areas, agriculture land).

over 5 rooms and are specific to old houses in downtown Bucharest, and have high seismic risk. In 2002, these categories did not yet include the large number of new houses or apartments built since then.

Spatial constraints were added in order to indicate the built-up areas for each census unit (Boolean maps true/false), but they were not considered during the weighting process. For more information about standardization and weighting methods using SMCE module of ILWIS software see Nijmeijer et al. (2001); Abella and Van Westen (2007); van Westen and Woldai (2012). Final results were standardized using $Z$ scores and represented in terms of standard deviation (Fig. 5).

To test geographic variability of results, we used Global Moran's I and Local Moran's I/LISA (local indicators of spatial association) statistics, implemented in the OpenGeoda software (Anselin et al., 2006).

The mere visualization of cartographic representation may often hide relevant aspects, accessible only through visual statistical techniques. There are plenty of scientific arguments in the literature that support the development of spatial autocorrelation techniques (Moran's I, LISA), that allow for data exploration under the spatial analysis of social vulnerability clusters.

The methodology of exploratory spatial data analysis (ESDA) for spatial clustering consists of three stages:

- Data observation using maps and histograms that may reveal the so-called "islands" (unconnected observation). The solution for constructing the weighted matrix, based on the exploration of data, was the selection of topological contiguity ( $k$ neighbourhood); it showed to be robust.

- Assessing the statistical significance through global Moran's I scatter plot, where the upper-right and lowerleft sections/quadrants reveal that social vulnerability data are above, or respectively, below the mean. This stage displays the existence of spatial clusters as the census tracts with high vulnerability are adjacent to each other, and vice-versa. On the other two quadrants are the outliers that depict cases in which high vulnerability areas may be close to the lower data, or the other way around.

- Testing the significance of LISA at different statistical levels, to see their form of spatial association (same as in step two, only that now Moran's I shows the location both in the scatter plot and the two resulting maps).

\section{Results}

\subsection{Spatial distribution}

In this study, empirical evidence (Gall, 2007) supported the validation of vulnerability indices (Fig. 5) and it confirmed the results of other surveys in Bucharest (Armaș, 2006, 2008a,b; Armaș et al., 2008).

The spatial analysis (Fig. 5) revealed the prevalence of tracts with low scores of vulnerability. The social vulnerability of the city exists in the centre, with some exceptions, and spreads towards the outskirts. An important aspect is the similarity of the results obtained from the two maps.

To view the spatial variation of the high social vulnerability parameter, we chose to integrate all areas identified as exceeding the threshold value of $1 \mathrm{SD}$. Together, the vulnerable areas (labeled with $+1 \mathrm{SD}$ ) accumulate 21 census units in case of SoVI (13.6\%), respectively 20 for SEVI (12.9\%). The tract with the highest social vulnerability overlays the Ferentari neighbourhood in both indices cases (4.32 in the SoVI case, and 2.27 for SEVI). Areas of high social vulnerability are predominantly in the outskirts, but some of them are revealed in the central area. Predisposition for high social vulnerability in some central zones of Bucharest is a known problem, which occurred and developed especially after 1990. Here, inhabitants on low incomes settled, occupying buildings under construction or in an advanced state of decay. For this reason, it is difficult to implement intervention measures to rebuild the downtown and to undergo the seismic retrofit of the old buildings in the centre of the city. Regarding the peripheral areas, we notice that many of them are the results of poor integration of the suburbs during communism. Back then, nearby suburban localities were included within the city limits, and the population, which became urban, was unable to efficiently adapt to the conditions of the new living 
environment. This failure to adapt should be understood as the result of a culture shock between the rural and archaic lifestyle and the socialist working class culture. The newly declared urban population (over $50 \%$ of the Bucharest population was born outside the city, until 2002) preserved the living conditions of rural life, despite living in a city or in a block of flats. While it may sound odd, some of the inhabitants of these areas preferred to improvise dwellings for their animals (pigs, hens and others) and themselves from poor materials and with no authorization for construction. Even now, peripheral areas retain some of the rural characteristics. The population is socially dependent, the families living on low incomes are numerous, and education is a problem both from the point of view of the number of schools as well as their level/quality. This description expresses that the most powerful factors involved in influencing social vulnerability in Bucharest are the economic level, education, and the political measures before and after the change of the communist regime in 1990. Since political measures could not be quantified in the study, the other factors are the measure of the impact.

In the category labelled as the least vulnerable (values under $-1 \mathrm{SD}$ ) attention aims towards the census unit, which includes the former area of concentration of the political and economic elite before 1990. The Primăverii area is located in the central-northern part of the city, sector 1 . In the case of SEVI mapping, it is accompanied by a similar area from the central-western part, called Cotroceni. The image of reduced social vulnerability varies to different degrees at the two indices. In the central part of the city, in sector 3, SEVI indicates low vulnerability, while SoVI renders to the mean. In many cases, the population in these areas comprises people employed in the private sector who earn above-average wages, are well trained and have high education levels. But they are outlined only in the zones Primăverii and Cotroceni and thus low social vulnerability assessment remains the most difficult problem for Bucharest.

To confirm the vulnerable areas, and to better understand where the areas affected by social vulnerability are, as well as to discover the eventual spatial associations of cluster type, we performed an exploratory spatial data analysis.

\subsection{Spatial patterns}

The use of local indicators of spatial associations was further conducted to improve the decisions pending the assessment of the social vulnerability in Bucharest. Our goal was to find in what parts of the city the outliers of the social vulnerability indices are highly associated and what their spatial configuration is.

We paid attention to the identification of spatial patterns and to their degree of similarity. For this purpose, we explored the scatterplot of global Moran's I $\left(I_{\mathrm{SoVI}}=0.2562\right.$, $\left.I_{\mathrm{SEVI}}=0.1623\right)$ : it showed that there is a spatial pattern of social vulnerability in Bucharest for both cases (Fig. 6). To
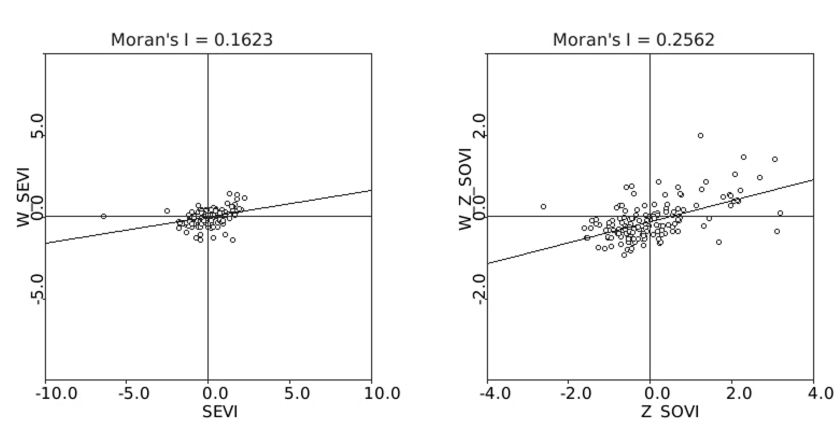

Fig. 6. Moran's I Scatterplot for Bucharest Social Vulnerability in 2002.

reveal the location of the indices clustering, we built local indicators of spatial association maps (LISA). Figure 7 records the social vulnerability in terms of LISA mapping, using a $k$ neighbourhood matrix. Areas of strong or weak association are identified and classified by the four types of spatial association: areas in red show high vulnerability, the blue areas represent low vulnerability, while the pink and light blue denote areas of vulnerability surrounded by the opposite type (high-low or low-high).

Our interest focused on the areas with high social vulnerability and on whether there is a match among clusters resulting from the two methods applied. As expected, significant spatial clustering areas, which overlap, were revealed (Fig. 7). They should be seen in a broader context of the map, because the spatial clusters colour representations of LISA indicates only the centre of the clusters. Mapping the two indices using LISA revealed a similarity among the clustering areas affected by high social vulnerability. The NW and SW areas in red are displayed in both variants. They were mainly influenced by the development of industry before the 1950s or during the early years of communism. These are areas with a high share of working class people, lacking many of the basic social facilities, and are based on the empirical perception and knowledge of the city. In fact, the negative image that these areas radiate aggravates even further the population's vulnerability.

Apart from these two obvious clusters, the local analysis of clustering indicates differences between the two indices. Thus, SoVI registers two additional areas in the central part of the map, where social vulnerability reached high values. They stem from the social evolution of the areas until 2000, when the central part of the city saw unequal initiatives of economic development that gradually gained local significance. Against this background, the presence of an elderly population, as well as elements such as lack of initiative, low wages or large number of persons in care, led to the formation of these clusters.

While in the case of social vulnerability, cluster analysis has been similar, there is a strong difference in terms of associated areas with values below mean levels, which indicate a 

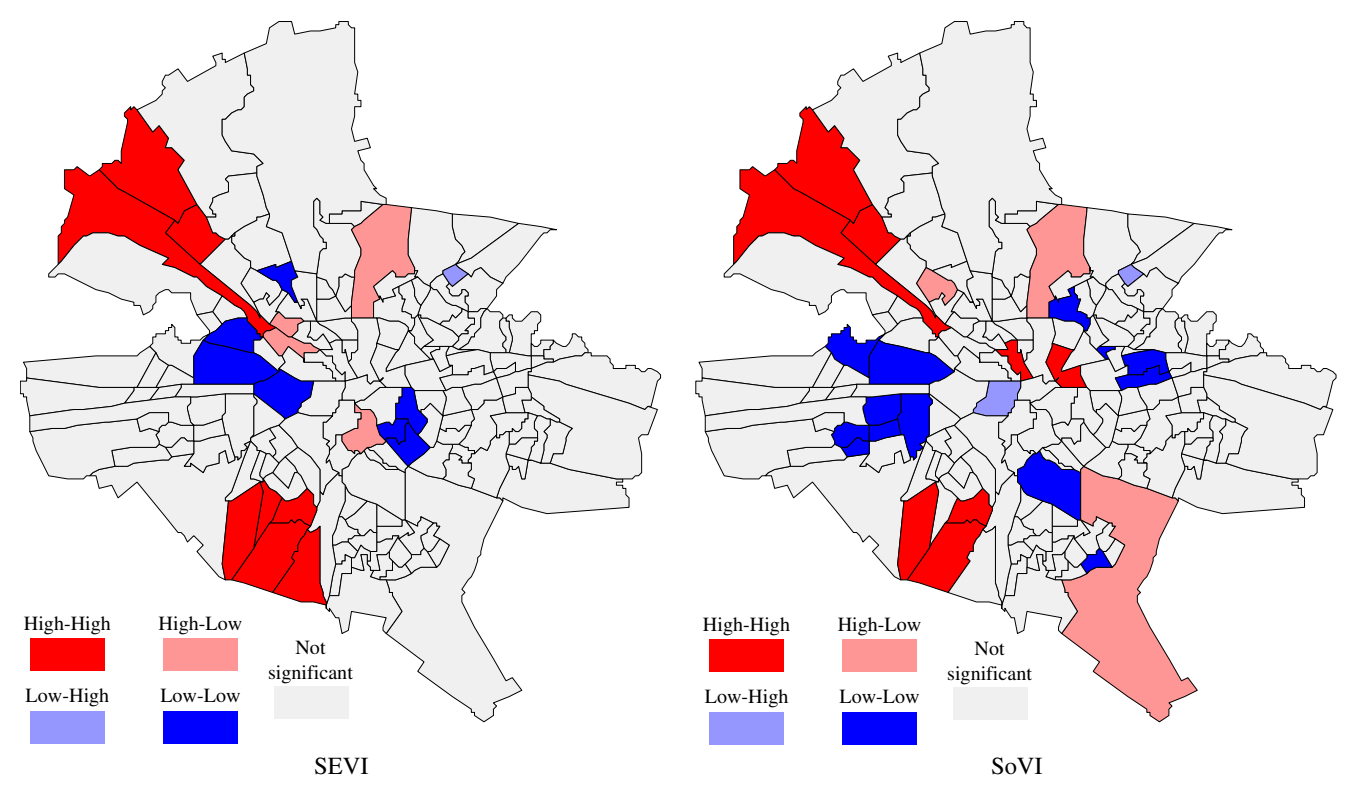

Fig. 7. LISA clusters maps.

low degree of exposure (low-low or cold spots). Although in the central-west part, pertaining to the south area of Militari district where the two indices display a similar range, differences remain significant. The map of the LISA analysis for SEVI shows the range of low social vulnerability advancing toward the Cotroceni district, while for SoVI, it stretches toward the west. Another significant range appears in the case of SoVI clustering, where low social vulnerability may be admitted. We have identified this area as Drumul Taberei, a popular district during communist times housing intellectual elites and people with high industrial technical backgrounds. Built between 1960s-1980s, this district appealed to many young people, with no statistically relevant social sensitivity. Other areas with low social vulnerability appear differently: SEVI pointed to an area in the central part of the capital, in sector 3, and SoVI highlighted a higher number of such areas stretching between the mixed area and the area of large housing units. We may add that, in both situations, these areas are located along main roads. Generally available in such locations, the social-economic facilities became attractive for the active, mobile population of Bucharest, young and adult, eager to use the facilities. The areas indicating outliers are disparate and are better highlighted by SEVI in terms of gathering. Since their distribution in ranges is so varied and reduced, one needs to further undertake a more detailed investigation. Our hypothesis on dissimilarity is that there may be other factors than the ones introduced in our analysis, which are likely to have a stronger influence on social vulnerability here. Also, considering the census of 2012, a new analysis may clarify the changes that only showed up in those areas.

\section{Discussion}

The identification of vulnerability and the understanding of related methodologies helps the development of policies and action plans for mitigation. Assessment of social vulnerability indices in relation to earthquake risk does this and adds to research from the natural hazards studies. In this paper, we applied a new proposed index - SEVI compared against a more common one, SoVI - and explored their spatial distribution. The assessment procedure of social vulnerability showed to be reliable and may determine the use of the results to enhance urban policy, introducing a scientifically argued solution, as a possible key-element for Romanian urban public policy.

The study indicated advantages and disadvantages of the indices in a social vulnerability context. The two indices overlapped the limitation of the available data that had an effect on the selection of indicators and their degree of representation. The uncertainty triggered by the standardization methods used, weighting and aggregation responded positively to the approach involved in the study (as all elements need to be classified, standardized/normalized and included into a category and a calculation algorithm, which can lead to misleading results). Factor analysis pointed towards the influence that susceptible population categories have on social vulnerability. These categories of population were on an upward trend at that time. Most results were confirmed by the disparate studies performed on certain aspects of vulnerability (Armaș, 2006, 2008b; Mionel, 2011).

The ESDA approach allowed for the investigation of the spatial distribution of social vulnerability in Bucharest. The identification of clustering spots prone to high vulnerability 
may lead authorities to prevent or diminish the catastrophic effects of earthquakes like those of 1940 and 1977. The application of ESDA over the two indices resulted in understanding the difference that may appear when a simple aggregation is conducted against a weighted one. While the maps reveal differences, both indices displayed on the maps exposed the vulnerability areas in a clear manner. Moreover, the consistency of analysis looks good, but a statistical testing through additional methods would improve it.

Although the proposed methods do not capture the concatenation of factors as highlighted by Wisner and Luce (1993), the main advantage observed in the paper was that the indices are relatively easy to apply, which could be a solution for different stakeholders keen to reduce social vulnerability in the city. Thus, social vulnerability assessment fits into the general approach of informing decision making (Schröter et al., 2005; Metzger and Schröter, 2006) and sets up a bridge among academic research, policy and practice (Steinführer et al., 2009; Gaillard, 2010).

The method for SoVI suggests that is easy to apply, regardless of scale (Schmidtlein, 2008) and, in most cases, uses variables, which are comparable to and well-sustained in the literature of the past decade. Still, the method needs not a simplistic approach, but thorough scientific expertise throughout its implementation, especially regarding the sign of aggregation of the PCA factors. There is a disadvantage in that the additive model inherently eliminates the separate relevance of factors. Thus, one cannot safely assess the impact of each factor within the general outcome, since it is only a statistical image.

Another disadvantage of SoVI is that it does not allow testing against an independent variable (Schmidtlein, 2008). As for other indices, in temporal analyses, SoVI bears comparison only to itself. These temporal analyses are not suitable for Bucharest, since census units have changed from one census to another and data becomes available only after a long period of time.

The spatial multi-criteria evaluation (SMCE) is a semiquantitative method, based on expert opinion. The uncertainty surrounding the validity of chosen weighting schemes is a major issue of the SMCE that makes the results difficult to compare or generalize from. The positive part is the accessibility of the method and the smoothness of interpretation of results by decision-makers. One additional advantage arises from structuring a complex problem into sub-levels or sub-goals.

The study emphasizes that social vulnerability is an urban process that is continually expanding in Bucharest, with a tendency towards extending clusters. The image of social vulnerability looks to be too good for the year and the conditions of Bucharest during the time of the 2002 census. At that time, the transformation of economy and society from communism to capitalism was at its peak and the urban population has become increasingly polarized. Some limitations arise from this as the two methods could not perceive and measure the influence of political factors to the vulnerability dynamics in the complex political situation of Bucharest after 1990. Nevertheless, further insight will develop once the 2012 census data is available and the assessment changes are analysed.

\section{Conclusions}

Although there is a statistically significant, but low, positive correlations between the two indices $(r=0.33$; $\mathrm{Sig}=0.001)$, the pair-sample $T$ test $(t=3.2$; Sig 2 -tailed $=0.001)$ indicates that the results after applying SoVI and SEVI are not similar. Therefore, the two methodologies cannot be used interchangeably. The option for one method or another depends on the scope of the study and the degree to which the researcher knows the issues of the study. SEVI methodology suggests more freedom of intervention on procedural steps and because of this is more responsive regarding expertopinion accuracy.

Furthermore, the procedure offers the possibility to highlight on purpose certain aspects that the researcher considers important or facilitates the segmentation of methodological flow at certain levels or sub-goals that can be analysed separately.

The diagnosis indicated by the image of social vulnerability clusters and the comparison of the two indices may offer a viable and integrative practical guide to authorities and policy makers. This could enhance measures to diminish the social vulnerability. It further suggests exploring the validation approach and the development in relation to different strategies involving assessment of social vulnerability. To international research it adds to the continuous interest of vulnerability metric development, enhancing the relevant literature. Scientifically, the paper covers a less explored area and assesses two convergent methods that prove practical value.

Acknowledgements. This work is partly funded by the EC projects PNII31007/2007 and PCE285/2011, I. Armaș. The authors would like to thank the reviewers for commenting the text and for theirs valuable suggestions made on this paper. Special thanks to Adele Youmans and all the people who provided insight on the paper at the IGC 2012.

Edited by: A. Steinführer

Reviewed by: V. Martins and two anonymous referees

\section{References}

Abella, E. and Van Westen, C.: Generation of a landslide risk index map for Cuba using spatial multi-criteria evaluation, Landslides, 4, 311-325, 2007.

Adger, W., Brooks, N., Kelly, M., Bentham, S., and Eriksen, S.: New indicators of vulnerability and adaptive capacity, vol. 122, Tyndall Centre for Climate Change Research, Norwich, UK, 2004. 
Adger, N., Arnell, N., and Tompkins, E.: Successful adaptation to climate change across scales, Global Environ. Chang., 15, 77-86, 2005.

Anderson, M. and Woodrow, P.: Rising from the ashes: development strategies in times of disaster, Westview Press, Boulder, 1989.

Anselin, L., Syabri, I., and Kho, Y.: GeoDa: An introduction to spatial data analysis, Geogr. Anal., 38, 5-22, 2006.

Armas, I.: Earthquake risk perception in Bucharest, Romania, Risk Anal., 26, 1223-1234, 2006.

Armaș, I.: Percepţia riscurilor naturale: cutremure, inundaţii, aluneări, Editura Universităţii din București, București, 2008a.

Armaș, I.: Social vulnerability and seismic risk perception, Case study: the historic center of the Bucharest Municipality/Romania, Nat. Hazards, 47, 397-410, 2008b.

Armaș, I. and Avram, E.: Patterns and trends in the perception of seismic risk, Case study: Bucharest Municipality/Romania, Nat. Hazards, 44, 147-161, 2008.

Armaș, I., Dumitrașcu, S., and Boștenaru, M.: Lucrările celei dea patra Conferinţe naţionale de inginerie seismică, chap. Analiza multicriterială de vulnerabilitate urbană la risc seismic, cu accent asupra fondului arhitectural: Municipiul București, Editura Conspress, București, 2008.

Babbie, E.: The practice of social research, Wadsworth Pub Co, Belmont, 2007.

Beck, U.: Risk society: Towards a new modernity, vol. 17, Sage Publications Limited, 1992.

Birkmann, J.: Indicators and criteria for measuring vulnerability: Theoretical bases and requirements, in: Measuring vulnerability to natural hazards: Towards disaster resilient societies, edited by: Birkmann, J., United Nations University, New York, Tokyo, 5577, 2006a.

Birkmann, J. (Ed.): Measuring vulnerability to promote disasterresilient societies: Conceptual frameworks and definitions, United Nations University Press, Tokyo, 2006b.

Birkmann, J. and Wisner, B.: Measuring the un-measurable, The challenge of vulnerability, SOURCE, 5/2006, available at: http: //www.ehs.unu.edu/file/get/3962 (last access: 27 April 2013), 2006.

Blaikie, P.: At risk: natural hazards, people's vulnerability, and disasters, Routledge, London, 1994.

Blaikie, P., Cannon, T., Davis, I. ., and Wisner, B.: At risk: natural hazards, people's vulnerability and disasters, Routledge, London, 2nd Edn., 2004.

Blaikie, P., Mainka, S., and McNeely, J.: The Indian Ocean tsunami: reducing risk and vulnerability to future natural disasters and loss of ecosystems services, Information paper, International Union for Conservation of Nature Information, Gland, Switzerland, available at: http://data.iucn.org/dbtw-wpd/edocs/ Rep-2005-006.pdf, 2005.

Bohle, H.: Vulnerability and criticality: perspectives from social geography, IHDP update, 2, 3-5, 2001.

Bohle, H., Downing, T., and Watts, M.: Climate change and social vulnerability: Toward a sociology and geography of food insecurity, Global Environ. Chang., 4, 37-48, 1994.

Booysen, F.: An overview and evaluation of composite indices of development, Soc. Indic. Res., 59, 115-151, 2002.

Borden, K., Schmidtlein, M., Emrich, C., Piegorsch, W., and Cutter, S.: Vulnerability of US cities to environmental hazards, J. Homel. Secur. Emerg., 4, 1-21, 2007.
Boruff, B. and Cutter, S.: The environmental vulnerability of Caribbean island nations, Geogr. Rev., 97, 24-45, 2007.

Boruff, B., Emrich, C., and Cutter, S.: Erosion hazard vulnerability of US coastal counties, J. Coastal. Res., 21, 932-942, 2005.

BSSA: Seismological Notes-July-August, B. Seismol. Soc. Am., 68, 1781-1783, 1978.

Burton, I. and White, G.: The environment as hazard, The Guilford Press, 1993.

Burton, I., Kates, R., and White, G.: The environment as hazard, Oxford University Press, Oxford, 1978.

Cardona, O.: Indicators of Disaster Risk and Risk Management main technical report, Report, IDB/IDEA Program of Indicators for Disaster Risk Management, National University of Columbia, Manizales, 2005.

Carmines, E. G. and Wood, J.: Index, in: The Sage encyclopedia of social science research methods, edited by: Lewis-Beck, M., Bryman, A., and Liao, T., Sage Publications, Inc, Thousand Oaks, vol. 1, 485-486, 2004.

Carver, S.: Developing web-based GIS/MCE: improving access to data and spatial decision support tools, in: Multicriteria decisionmaking and analysis: A geographic information sciences approach, edited by Thill, J.-C., pp. 49-76, Ashgate, New York, 1999.

Chakraborty, J., Tobin, G., and Montz, B.: Population evacuation: assessing spatial variability in geophysical risk and social vulnerability to natural hazards, Nat. Hazards Rev., 6, 23-33, 2005.

Chen, M., Tzeng, G., and Ding, C.: Combining fuzzy AHP with MDS in identifying the preference similarity of alternatives, Appl. Soft. Comput., 8, 110-117, 2008.

Cutter, S.: Vulnerability to environmental hazards, Prog. Hum. Geog., 20, 529-539, 1996.

Cutter, S. and Emrich, C.: Moral hazard, social catastrophe: The changing face of vulnerability along the hurricane coasts, Ann. Am. Acad. Polit. SS, 604, 102-112, 2006.

Cutter, S. and Finch, C.: Temporal and spatial changes in social vulnerability to natural hazards, P. Natl. Acad. Sci. USA, 105, 2301-2306, 2008.

Cutter, S., Holm, D., and Clark, L.: The role of geographic scale in monitoring environmental justice, Risk. Anal., 16, 517-526, 1996.

Cutter, S., Mitchell, J., and Scott, M.: Revealing the vulnerability of people and places: A case study of Georgetown County, South Carolina, Ann. Assoc. Am. Geogr., 90, 713-737, 2000.

Cutter, S., Boruff, B., and Shirley, W.: Social Vulnerability to Environmental Hazards, Soc. Sci. Quart., 84, 242-261, 2003.

Davidson, D. and Freudenburg, W.: Gender and environmental risk concerns, Environ. Behav., 28, 302-339, 1996.

Dayton-Johnson, J.: Natural Disasters and Adaptive Capacity, OECD Development Centre Working Papers, 237, doi:10.1787/827805005406, 2004.

de Oliveira Mendes, J.: Social vulnerability indexes as planning tools: beyond the preparedness paradigm, J. Risk. Res., 12, 4358, 2009.

Diener, E. and Suh, E.: Measuring quality of life: Economic, social, and subjective indicators, Soc. Indi. Res., 40, 189-216, 1997.

Dow, K.: Exploring differences in our common future(s): the meaning of vulnerability to global environmental change, Geoforum, 23, 417-436, 1992. 
Downing, T. and Patwardhan, A.: Assessing vulnerability for climate adaptation, in: Adaptation Policy Frameworks for Climate Change: Developing Strategies, Policies and Measures, edited by: Lim, B., Spanger-Siegfried, E., Burton, I., Malone, E., and Huq, S., Cambridge University Press, Cambridge and New York, 67-90, 2004.

Dowty, R. and Allen, L. (eds.): Dynamics of Disaster: Lessons on Risk, Response and Recovery, Earthscan, London, 2011.

Dwyer, A., Zoppou, C., Nielsen, O., Day, S., and Roberts, S.: Quantifying Social Vulnerability: A methodology for identifying those at risk to natural hazards, Geoscience Australia, 2004.

Dyck, E.: IHDP Update, Tech. rep., International Human Dimensions Programme on Global Environmental Change, 2001.

Eakin, H. and Luers, A.: Assessing the vulnerability of socialenvironmental systems, Annu. Rev. Environ. Resour., 31, 365394, 2006.

Ebert, A., Kerle, N., and Stein, A.: Urban social vulnerability assessment with physical proxies and spatial metrics derived from air and spaceborne imagery and GIS data, Nat. Hazards, 48, 275294, 2009.

Fekete, A.: Validation of a social vulnerability index in context to river-floods in Germany, Nat. Hazards Earth Syst. Sci., 9, 393403, doi:10.5194/nhess-9-393-2009, 2009.

Fekete, A.: Assessment of Social Vulnerability River Floods in Germany, Tech. Rep. 4, UNU-EHS, available at: http://www.ehs. unu.edu/file/get/8069 (last access: 27 April 2013), 2010.

Fekete, A., Damm, M., and Birkmann, J.: Scales as a challenge for vulnerability assessment, Nat. Hazards, 55, 729-747, 2010.

Fordham, M.: The place of gender in earthquake vulnerability and mitigation, in: Proceedings of the EuroConference on Global Change and Catastrophe Risk Management: Earthquake Risks in Europe, IIASA, available at: http://webarchive.iiasa. ac.at/Research/RMS/july2000/Papers/fordham0208.pdf (last access: 27 April 2013), 2000.

Fuchs, S., Heiss, K., and Hübl, J.: Towards an empirical vulnerability function for use in debris flow risk assessment, Nat. Hazards Earth Syst. Sci., 7, 495-506, doi:10.5194/nhess-7-4952007, 2007.

Fuchs, S., Kuhlicke, C., and Meyer, V.: Editorial for the special issue: vulnerability to natural hazards - the challenge of integration, Nat. Hazards, 52, 1-11, 2011.

Füssel, H.: Vulnerability in climate change research: A comprehensive conceptual framework, Tech. rep., University of California, International and Area Studies - Breslauer Symposium No. 6k, 2005.

Füssel, H.: Adaptation planning for climate change: concepts, assessment approaches, and key lessons, Sustain. Sci., 2, 265-275, 2007a.

Füssel, H.: Vulnerability: A generally applicable conceptual framework for climate change research, Global Environ. Chang., 17, 155-167, 2007b.

Füssel, H.: Review and quantitative analysis of indices of climate change exposure, adaptive capacity, sensitivity, and impacts, Background note to the world development report 2010 on development and climate change, 2009.

Gaillard, J.: Vulnerability, capacity and resilience: perspectives for climate and development policy, J. Int. Develop., 22, 218-232, 2010.
Gall, M.: Indices of social vulnerability to natural hazards: A comparative evaluation, Ph.D. thesis, University of South Carolina, Department of Geography Doctoral Dissertation, available at: http://webra.cas.sc.edu/hvri/education/docs/Melanie_ Gall_2007.pdf (last access: 27 April 2013), 2007.

Giardini, D., Grünthal, G., Shedlock, K. M., and Zhang, P.: The GSHAP global seismic hazard map, Ann. Geophys., 42, 12251228, 1999,

http://www.ann-geophys.net/42/1225/1999/.

Guillaumont, P. and Simonet, C.: Designing an index of structural vulnerability to climate change, FERDI Working paper 08, available at: http://www.ferdi.fr/uploads/sfCmsContent/ html/112/I8-Guillaumont-Simonet.pdf (last access: 12 August 2012), 2011.

Haas, J., Kates, R., and Bowden, M. (Eds.): Major insights: A summary and recommendations, chap. 6, pp. 261-293, The MIT Press environmental studies series, The MIT Press, Cambridge, MA, 1977.

Hewitt, K.: Regions of risk: A geographical introduction to disasters, Longman, London, 1997.

Holand, I. S. and Lujala, P.: Replicating and Adapting an Index of Social Vulnerability to a New Context: A Comparison Study for Norway, Prof. Geogr., 65, 312-328, doi:10.1080/00330124.2012.681509, 2013.

Holand, I. S., Lujala, P., and Rød, J.: Social vulnerability assessment for Norway: A quantitative approach, Norsk Geogr. Tidsskr., 65, $1-17,2011$.

Howard, A.: A critical look at multiple criteria decision making techniques with reference to forestry applications, Can. J. Forest. Res., 21, 1649-1659, 1991.

Ionescu, C., Klein, R., Hinkel, J., Kavi Kumar, K., and Klein, R.: Towards a formal framework of vulnerability to climate change, Environ. Model. Assess., 14, 1-16, 2009.

Jean-Baptiste, N., Kuhlicke, C., Kunath, A., and Kabisch, S.: Review and evaluation of existing vulnerability indicators for assessing climate related vulnerability in Africa, UFZ Reports 07/2011, UFZ-Bericht, Helmholtz-Zentrum für Umweltforschung, available at: http://hdl.handle.net/10419/57865 (last access: 27 April 2013), 2011.

Jolliffe, I.: Principal component analysis, Wiley Online Library, New York, 2005.

Kasperson, J. and Kasperson, R.: The Social Contours of Risk: Risk analysis, corporations \& the globalization of risk, 1-2, Earthscan, London, 2005.

Kasperson, R. and Berberian, M.: Integrating science and policy: vulnerability and resilience in global environmental change, Earthscan Publications Ltd, London, 2011.

Kates, R.: The interaction of climate and society, in: Climate Impact Assessment. Studies of the Interaction of Climate and Society, edited by: Kates, R., Ausubel, J., and Berberian, M., Wiley, Chichester, UK, 3-36, 1985.

Keefer, D., Kirkwood, C., and Corner, J.: Perspective on decision analysis applications, 1990-2001, Decision Analys., 1, 4-22, 2004.

Keeney, R.: Value-focused thinking: A path to creative decision making, Harvard University Press, Cambridge, 1992.

Lang, D., Molina-Palacios, S., Lindholm, C., and Balan, S.: Deterministic earthquake damage and loss assessment for the city of Bucharest, Romania, J. Seismo., 16, 1-22, 2011. 
Levine, C.: The concept of vulnerability in disaster research, J. Trauma Stress., 17, 395-402, 2004.

Liverman, D.: Vulnerability to global environmental change, in: Understanding Global Environmental Change, edited by: Kasperson, R., Dow, K., Golding, K., and Kasperson, J., Worcester, MA, Clark University, chap. 4, 27-47, 1990.

Lopes, H., Schmidt, A., Salazar, E., Gómez, M., and Achkar, M.: Measuring the vulnerability of the Uruguayan population to vector-borne diseases via spatially hierarchical factor models, Ann. Appl. Stat., 6, 284-303, doi:10.1214/11-AOAS497, 2012.

Malczewski, J.: GIS and multicriteria decision analysis, Wiley \& Sons, New York, 1999.

Mândrescu, N. and Radulian, M.: Seismic microzoning of Bucharest (Romania): A critical review, in: Vrancea Earthquakes: Tectonics, Hazard, and Risk Mitigation, Kluwer Academic Publishers, Dordrecht, 109-122, 1999.

Mândrescu, N., Radulian, M., and Mărmureanu, G.: Geological, geophysical and seismological criteria for local response evaluation in Bucharest urban area, Soil. Dyn. Earthq. Eng., 27, 367393, 2007.

Marchand, M.: Modelling coastal vulnerability: design and evaluation of a vulnerability model for tropical storms and floods, vol. 5, IOS Press, Amsterdam, 2009.

Mărmureanu, G., Cioflan, C., and Mărmureanu, A.: Intensity seismic hazard map of Romania by probabilistic and (neo) deterministic approaches, linear and nonlinear analyses, Rom. Rep. Phys., 63, 226-239, 2011.

McEntire, D.: Understanding and reducing vulnerability: from the approach of liabilities and capabilities, Disaster Prevent. Manage., 20, 294-313, 2011.

Metzger, M. and Schröter, D.: Towards a spatially explicit and quantitative vulnerability assessment of environmental change in Europe, Reg. Environ. Change, 6, 201-216, 2006.

Miller, F., Osbahr, H., Boyd, E., Thomalla, F., Bharwani, S., Ziervogel, G., Walker, B., Birkmann, J., van der Leeuw, S., Rockström, J., Hinkel, J., Downing, T., Folke, C., and Nelson, D.: Resilience and vulnerability: complementary or conflicting concepts, Ecol. Soc., 15, 11, 2010.

Mionel, V.: Segregare urbană, Separaţi, dar împreună, Editura Universitară, București, 2011.

Mitchell, J.: What's in a name?: Issues of terminology and language in hazards research, Global Environ. Chang. Part B, 2, 87-88, 2000.

Morath, D.: Social vulnerability and public health: Developing a metric for medical emergency management in Florida, Phd, University of South Carolina, available at: http://webra.cas.sc.edu/ hvri/education/docs/Dan_Morath_2010.pdf (last access: 27 april 2013), 2010.

Morrow, B.: Identifying and mapping community vulnerability, Disasters, 23, 1-18, 1999.

Munda, G. and Nardo, M.: On the methodological foundations of composite indicators used for ranking countries, in: Proceeding of the First OECD/JRC Workshop on Composite Indicators of Country performance, Joint Research Centre of the European Communities, Ispra, Italy, 2003.

Mustafa, D., Ahmed, S., Saroch, E., and Bell, H.: Pinning down vulnerability: from narratives to numbers, Disasters, 35, 62-86, 2011.
Nardo, M., Saisana, M., Saltelli, A., and Tarantola, S.: Tools for Composite Indicators Building, in: European Commission, EUR 21682 EN, Institute for the Protection and Security of the Citizen, JRC Ispra, Italy, 131 pp., 2005.

Niemeijer, D.: Developing indicators for environmental policy: data-driven and theory-driven approaches examined by example, Environ. Sci. Policy, 5, 91-103, 2002.

Nijmeijer, R., de Haas, A., Dost, R., and Budde, P.: ILWIS 3.0 academic user's guide, 3.0, 2001.

O'Keefe, P., Westgate, K., and Wisner, B.: Taking the naturalness out of natural disasters, Nature, 260, 566-567, 1976.

Papathoma-Köhle, M., Kappes, M., Keiler, M., and Glade, T.: Physical vulnerability assessment for alpine hazards: state of the art and future needs, Nat. Hazards, 58, 645-680, 2011.

Pelling, M.: The vulnerability of cities: natural disasters and social resilience, Earthscan, London, 2003.

Petak, W. and Atkisson, A.: Natural hazard risk assessment and public policy: anticipating the unexpected, Springer-Verlag, New York, 1982.

Preston, B., Yuen, E., and Westaway, R.: Putting vulnerability to climate change on the map: a review of approaches, benefits, and risks, Sustain. Sci., 6, 177-202, 2011.

Radulian, M., Mândrescu, N., and Grecu, B.: Seismic ground motion variability over the Bucharest area, Acta Geod. Geophysa. Hu., 41, 361-368, 2006.

Rashed, T. and Weeks, J.: Exploring the spatial association between measures from satellite imagery and patterns of urban vulnerability to earthquake hazards, International Archives of the Photogrammetry, Remote Sens. Spat. Inf. Sci., 34, 144-152, 2003.

Renn, O. and Walker, K.: Lessons Learned: A Re-Assessment of the IRGC Framework on Risk Governance, in: Global Risk Governance, edited by: Renn, O. and Walker, K., vol. 1 of International Risk Governance Council Bookseries, Springer, Netherlands, 331-367, doi:10.1007/978-1-4020-6799-0_14, 2008.

Rygel, L., O'sullivan, D., and Yarnal, B.: A method for constructing a social vulnerability index: an application to hurricane storm surges in a developed country, Mitigation Adapt. Strat. Global Change, 11, 741-764, 2006.

Saaty, T.: Analytic hierarchy process, McGraw Hill, New York, 1980.

Saaty, T.: Decision making with the analytic hierarchy process, Int. J. Services Sci., 1, 83-98, 2008.

Schmidtlein, M.: Spatio-temporal changes in the social vulnerability of Charleston, South Carolina from 1960 to 2010, Ph.D. thesis, University of South Carolina, available at: http://webra. cas.sc.edu/hvri/education/docs/Matt_Schmidtlein_-2008.pdf (last access: 27 april 2013), 2008.

Schmidtlein, M., Deutsch, R., Piegorsch, W., and Cutter, S.: A sensitivity analysis of the social vulnerability index, Risk Anal., 28, 1099-1114, 2008.

Schröter, D., Polsky, C., and Patt, A.: Assessing vulnerabilities to the effects of global change: an eight step approach, Mitigation Adapt. Strat. Global Change, 10, 573-595, 2005.

Simpson, D. and Katirai, M.: Indicator issues and proposed framework for a disaster preparedness index (DPi), Tech. Rep. 3, Center for Hazards Research and Policy Development, available at: http://hazardcenter.louisville.edu/pdfs/wp0603.pdf (last access: 27 april 2013), 2006. 
Stângă, I. C. and Grozavu, A.: Quantifying human vulnerability in rural areas: case study of Tutova Hills (Eastern Romania), Nat. Hazards Earth Syst. Sci., 12, 1987-2001, doi:10.5194/nhess-121987-2012, 2012.

Steinführer, A., Kuhlicke, C., DeMarchi, B., Scolobig, A., Tapsell, S., and Tunstall, S.: Local communities at risk from flooding: social vulnerability, resilience and recommendations for flood risk management in Europe, Report, Helmholtz Center for Environmental Research-UFZ, Leipzig, 2009.

Suditu, B.: Mobilitatea rezidenţială a populaţiei Municipiului Bucureşti, Ph.D. thesis, University of Bucharest, 2007.

Sunstein, C.: Risk and reason: Safety, law, and the environment, Cambridge University Press, 2002.

Susman, P., O'Keefe, P., and Wisner, B.: Global disasters, a radical interpretation, in: Interpretations of calamity from the viewpoint of human ecology, edited by: Hewitt, K., Allen \& Unwin, Winchester, MA, 264-283, 1983.

Tapsell, S., Penning-Rowsell, E., Tunstall, S., and Wilson, T.: Vulnerability to flooding: health and social dimensions, Philos. T. R. Soc. A., 360, 1511-1525, 2002.

Tapsell, S., Tunstall, S., Green, C., and Fernandez, A.: Task 11 Social Indicator Set, Tech. rep., FLOODsite report T11-07-01, available at: www.floodsite.net (last access: 16 January 2013), 2005.

Tapsell, S., McCarthy, S., Faulkner, H., and Alexander, M.: Social vulnerability to natural hazards, State of the art Report from CapHaz-Net's WP4, Flood Hazard Research Centre-FHRC, Middlesex University, London, available at: http://caphaz-net.org/outcomes-results/CapHaz-Net_WP4_ Social-Vulnerability.pdf (last access: 16 January 2013), 2010.

Tate, E.: Social vulnerability indices: a comparative assessment using uncertainty and sensitivity analysis, Nat. Hazards, 63, 1-23, 2012.

Thywissen, K.: Core terminology of disaster reduction: A comparative glossary, in: Measuring Vulnerability to natural hazards: towards disaster resilient societies, edited by: Birkmann, J., United Nations University Press, New York, Tokyo, 448-496, 2006.

Timmerman, P.: Vulnerability, resilience, and the collapse of society, in: Environmental Monograph, vol. 1, Institute for Environmental Studies, University of Toronto, Toronto, 1981.

Tobler, W.: A computer movie simulating urban growth in the Detroit region, Econ. Geogr., 46, 234-240, 1970.

Turner, B., Kasperson, R., Matson, P., McCarthy, J., Corell, R., Christensen, L., Eckley, N., Kasperson, J., Luers, A., Martello, M. L., Polsky, C., Pulsipher, A., and Schiller, A.: A framework for vulnerability analysis in sustainability science, Proc. Natl. Acad. Sci., 100, 8074, doi:10.1073/pnas.1231335100, 2003.

Twigg, J.: Sustainable livelihoods and vulnerability to disasters, Tech. rep., Benfield UCL Hazard Research Centre, London, 2001.

UNDRO: Natural disasters and vulnerability analysis, Tech. rep., Office of the United Nations Disaster Relief Co-ordinator, Geneva, 1982.

UN/ISDR: Living with risk: a global review of disaster reduction initiatives, vol. 1, United Nations Publications, Geneva, 2004. van Westen, C. and Woldai, T.: The RiskCity Training Package on Multi-Hazard Risk Assessment, Int. J. Appl. Geospat. Res., 3, 41-52, 2012.

Vargas, L.: An overview of the analytic hierarchy process and its applications, Eur. J. Oper. Res., 48, 2-8, 1990.

Villagran de Leon, J.: Vulnerability assessment: the sectoral approach, in: Measuring Vulnerability to Natural Hazards: Towards Disaster-Resilient Societies, edited by: Birkmann, J., United Nations University Press, Tokyo, 300-315, 2006.

Vincent, K.: Creating an index of social vulnerability to climate change for Africa, Working paper, Tyndall Center for Climate Change Research and University of East Anglia, Norwich, 2004.

Voogd, H.: Multicriteria evaluation for urban and regional planning, Pion, London, 1983.

WB: Romania - Post Earthquake Construction Assistance Project, Report P-2240-RO, World Bank. Washington, DC, Washington, DC, available at: http://documents.worldbank.org/curated/en/1978/05/1557071/ (last access: 18 January 2013), 1978.

Weichselgartner, J.: Disaster mitigation: the concept of vulnerability revisited, Disaster Prevent. Manage., 10, 85-95, 2001.

Westgate, K. and O'Keefe, P.: Some Definitions of Disaster, Bradford Disaster Research Unit, Occasional paper no. 4, Department of Geography, University of Bradford, 1976.

White, G.: Natural hazards research, in: Directions in geography, edited by: Chorley, R., Metheun \& Co. Ltd, London, 193-216, 1973.

Wisner, B.: Self-assessment of coping capacity: participatory, proactive and qualitative engagement of communities in their own risk management, in: Measuring Vulnerability To Natural Hazards: Toward Disaster Resilient Communities, edited by: Birkmann, J., United Nations University Press, New York, Tokyo, 316-328, 2006.

Wisner, B. and Luce, H.: Disaster vulnerability: Scale, power and daily life, GeoJournal, 30, 127-140, 1993.

Yarnal, B.: Vulnerability and all that jazz: Addressing vulnerability in New Orleans after Hurricane Katrina, Technol. Soc., 29, 249255, 2007.

Yeletaysi, S., Ozceylan, D., Fiedrich, F., Harrald, J., and Jefferson, T.: A framework to integrate social vulnerability into catastrophic natural disaster preparedness planning, in: The International Emergency Management Society-TIEMS 16th Annual Conference, 380-389, 2009.

Yusuff, R., Yee, K., and Hashmi, M.: A preliminary study on the potential use of the analytical hierarchical process (AHP) to predict advanced manufacturing technology (AMT) implementation, Robot Cim-Int Manuf, 17, 421-427, 2001.

Zaharia, B., Radulian, M., Popa, M., Grecu, B., Bala, A., and Tătaru, D.: Estimation of the local response using Nakamura method for Bucharest area, Rom. Rep. Phys., 60, 131-144, 2008.

Zeng, T. and Zhou, Q.: Optimal spatial decision making using GIS: a prototype of a real estate geographical information system (REGIS), Int. J. Geogr. Inf. Sci., 15, 307-321, 2001.

Zou, L. and Thomalla, F.: The Causes of Social Vulnerability to Coastal Hazards in Southeast Asia, Working papers, Stockholm Environment Institute, Stockholm, Sweden, 2008. 